\title{
Membangkitkan minat belajar Geografi dengan Google Earth pada peserta didik kelas XI IPS
}

\author{
Riyadi \\ SMA Negeri 1 Karangrayung, Kabupaten Grobogan, Indonesia
}

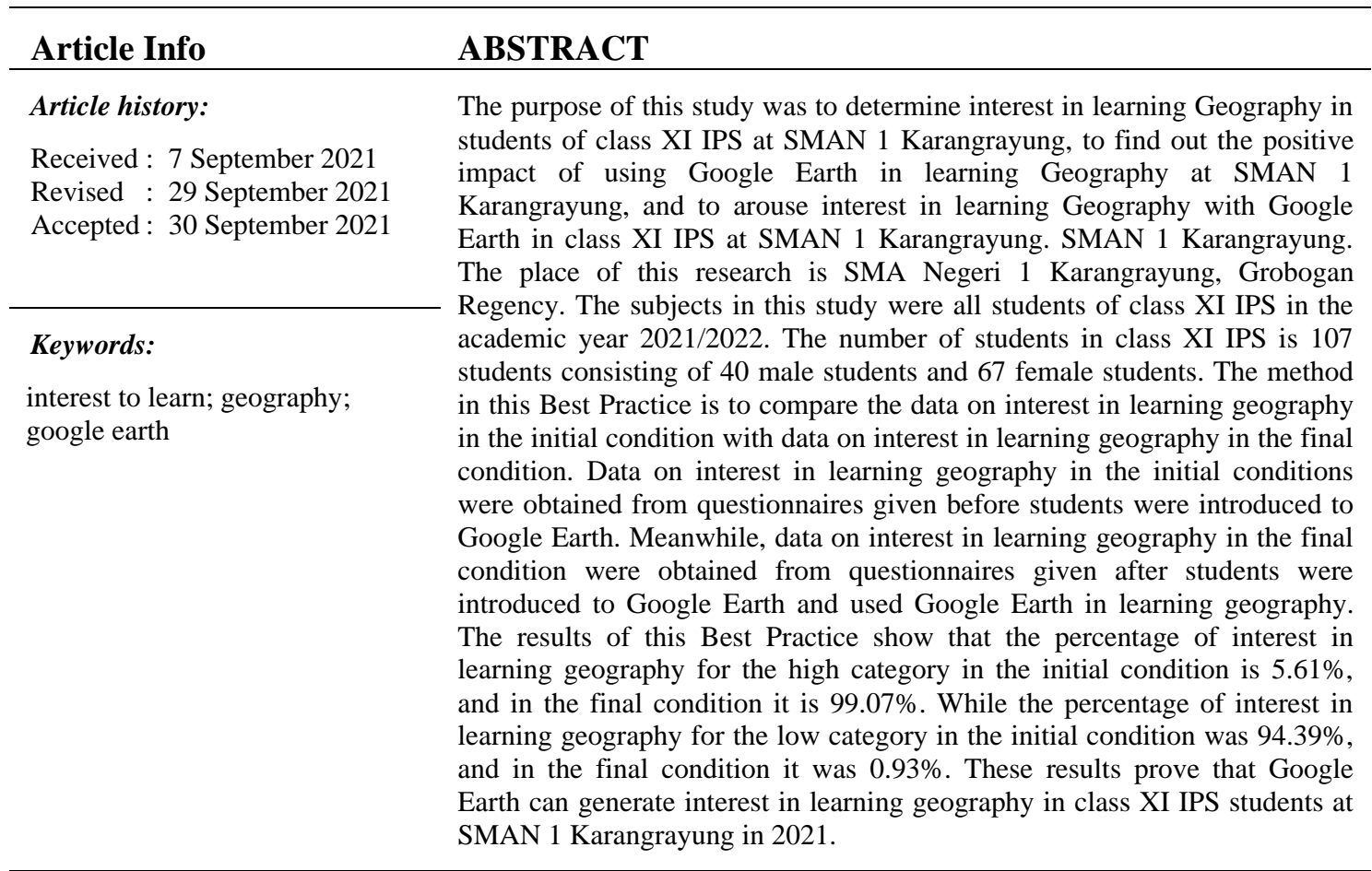

(*) Corresponding Author: $\quad$ riyadixxxx@gmail.com

How to Cite: Riyadi, R (2021). Membangkitkan minat belajar Geografi dengan Google Earth pada peserta didik kelas XI IPS, Action Research Journal, 1(1): 153-156.

\section{PENDAHULUAN}

Virus corona (Coronavirus) atau Covid-19 ditemukan pertama kali di kota Wuhan, China pada akhir tahun 2019 silam. Ada lebih dari 200 negara di dunia yang telah melaporkan warga negaranya yang terkena wabah virus corona ini (Yunita, 2020). Penyebaran virus corona ini pada awalnya sangat berdampak bagi dunia ekonomi yang mulai lesu, dan akhirnya kini juga berdampak pada dunia pendidikan. Kebijakan yang sudah diambil oleh banyak negara dan termasuk Negara Indonesia dengan meliburkan seluruh aktivitas pendidikan, dan membuat pemerintah dan lembaga terkait harus menemukan solusi alternatif untuk proses pendidikan bagi peserta didik (Dewi, 2020).

Dengan adanya virus Covid-19 ini membuat pembelajaran yang dilaksanakan di sekolahsekolah menjadi berubah dari yang semula tatap muka kemudian menjadi pembelajaran jarak jauh. Di sisi lain guru masih tetap harus melaksanakan kewajibannya sebagai pengajar, dimana guru harus tetap melaksanakan tugasnya yaitu mendidik agar peserta didik dapat menerima ilmu pengetahuan sesuai dengan bidangnya (Aulia, 2020). Di Indonesia, pembelajaran jarak jauh atau daring ini dimulai pada tanggal 16 Maret 2020, peserta didik belajar dari rumahnya masing-masing tanpa harus berangkat ke sekolah untuk belajar. Pembelajaran daring menuntut 
guru dalam penguasaan ilmu teknologi agar pembelajaran jarak jauh tetap berjalan dengan efektif dan efisien.

Pada pembelajaran daring peserta didik berinteraksi dengan guru menggunakan beberapa aplikasi yang di pakai seperti Google Classroom, Zoom, Google Meet, Whatsapp Group dan lain sebagainya. Pembelajaran dilaksanakan melalui komputer atau laptop yang terhubung dengan koneksi jaringan internet. Guru juga dapat melakukan pembelajaran bersama di waktu yang sama menggunakan grup di media sosial seperti media Whatsapp (WA), Telegram, Instagram, aplikasi Zoom ataupun media lainnya sebagai media pembelajaran. Sehingga guru dapat memastikan peserta didik mengikuti pembelajaran dalam waktu yang bersamaan, meskipun di tempat yang berbeda.

Ada beberapa hal yang perlu diperhatikan dalam pelaksanaan pembelajaran daring, yaitu bagaimana caranya agar peserta didik tetap semangat dalam belajar. Perlu inovasi dalam pembelajaran pada kondisi saat ini untuk membangkitkan minat belajar peserta didik. Minat belajar merupakan salah satu faktor yang sangat penting dalam menentukan keberhasilan belajar peserta didik, karena minat belajar itu muncul dari dalam diri peserta didik itu sendiri. Peran guru sangat penting untuk menumbuhkan minat belajar peserta didik, salah satunya dengan cara mengajar yang menyenangkan, dan memberikan motivasi yang dapat membangkitkan minat belajar peserta didik (Riamin, 2016).

Pelaksanaan pembelajaran di SMAN 1 Karangrayung melalui daring pada awalnya tidak ada kendala, namun setelah dilaksanakan pembelajaran secara daring tidak berjalan dengan baik. Penyebabnya adalah peserta didik mulai bosan dengan model pembelajaran daring yang selama ini digunakan oleh sebagian besar guru yaitu dengan hanya memberikan materi pelajaran kemudian peserta didik diminta membaca materi tersebut. Selanjtnya peserta didik diminta mengerjakan tugas yang diberikan guru melalui WA ataupun melalui google classroom. Solusi untuk mengatasi kejenuhan atau kebosanan peserta didik pada saat mengikuti pelajaran geografi, peserta didik akan diperkenalkan Google Earth. Melalui Google Earth ini peserta didik seakan-akan dibawa terbang mengitari bumi ini, sehingga dapat dapat melihat beberapa tempat yang ada di bumi ini. Melalui Google Earth ini diharapkan dapat membangkitkan minat belajar peserta didik.

Minat belajar adalah suatu rasa untuk menyukai atau juga tertarik pada suatu hal dan aktivitas belajar tanpa ada yang menyuruh untuk belajar (Ricardo \& Meilani, 2017). Minat belajar juga merupakan faktor pendorong untuk peserta didik dalam belajar yang didasari atas ketertarikan atau juga rasa senang keinginan iswa itu untuk belajar. Minat belajar merupakan sikap ketaatan dalam kegiatan proses belajar, baik yang menyangkut perencanaan jadwal belajar yang dimilikinya maupun inisiatif dirinya sendiri melakukan usaha tersebut dengan bersungguh- sungguh dalam belajar (Andriani \& Rasto, 2019).

Indikator minat belajar geografi dirumuskan sebagai berikut: (1) Peserta didik tertarik dan senang untuk belajar geografi, (2) Peserta didik ikut berpasrtisipasi aktif dalam belajar geografi, (3) Peserta didik memperhatikan dan konsentrasi dalam belajar geografi, (4) Peserta didik memiliki perasaan positif dan kemauan belajar geografi yang terus meningkat, (5) Peserta didik merasa nyaman pada saat belajar geografi, dan (6) Peserta didik memiliki kapasitas dalam membuat keputusan berkaitan dengan proses belajar geografi (Yunitasari \& Hanifah, 2020).

Google Earth merupakan sebuah program globe virtual yang sebenarnya disebut Earth Viewer dan dibuat oleh Keyhole, Inc. Program ini memetakan bumi dari superimposisi gambar yang dikumpulkan dari pemetaan satelit, fotografi udara dan globe GIS 3D. Awalnya dikenal sebagai Earth Viewer, pada tahun 2004 diambil alih oleh Google, kemudian pada tahun 2005 diganti namanya jadi Google Earth. Peluncuran Google Earth menyebabkan sebuah peningkatan lebih pada cakupan media mengenai globe virtual antara tahun 2005 dan 2006, menarik perhatian publik mengenai teknologi dan aplikasi geospasial. Globe virtual ini memperlihatkan rumah, warna mobil, dan bahkan bayangan orang dan rambu jalan. Resolusi yang tersedia tergantung pada tempat yang dituju, tetapi kebanyakan daerah dicakup dalam resolusi 15 meter. 
Google Earth membolehkan pengguna mencari alamat, dengan memasukkan koordinat, atau menggunakan mouse untuk mencari lokasi.

Google Earth bisa dibuka melalui komputer, Android, iPhone dan iPad. Adapun langkah-langkah atau tahapan dalam menggunakan Google Earth sebagai berikut: (1) Buka Google Earth, tahap pertama pengguna harus membuka melalui web di laman https://www.google.com/earth/ atau dengan menggunakan aplikasi Google Earth. Kemudian, klik 'telusuri' maka pengguna akan dilihatkan gambaran dunia. Untuk menelusuri Google Earth, pengguna bisa mengklik atau menyeret gambar; (2) Lokasi, tahap kedua menggunakan Google Earth dengan mengaktifkan garis kisi. Hal itu dilakukan untuk mengetahui titik koordinat geografis dan perkiraan pengguna berada; (3) Tampilan 3D, tahap ketiga aktifkan 3D. Tidak semua lokasi di Google Earth menampilkan gambar secara 3D. Namun, bila ingin menampilkan gambar bisa dilakukan dengan klik 'menu' kemudian pilih 'gaya peta', lalu 'aktifkan bangunan 3D; dan (4) Proses Pemuatan Gambar, tahap keempat lakukan pemutaran gambar.

\section{METODE}

Metode dalam Best Practice ini dengan membandingkan antara data minat belajar geografi pada kondisi awal dengan data minat belajar geografi pada kondisi akhir. Data minat belajar geografi pada kondisi awal diperoleh dari kuisioner yang diberikan sebelum peserta didik dikenalkan Google Earth. Sedangkan data minat belajar geografi pada kondisi akhir diperoleh dari kuisioner yang diberikan setelah peserta didik dikenalkan Google Earth dan menggunakan Google Earth dalam belajar geografi.

Pelaksanaan dari awal hingga akhir dalam menyusun Best practice ini selama 3 bulan, dimulai pada bulan Juli 2021sampai bulan September 2021. Penelitain Best practice ini dilaksanakan di SMAN 1 Karangrayung. Subjek pada Best practice ini semua peserta didik kelas XI IPS. Jumlah subjek sebanyak 107 peserta didik yang terdiri 40 laki-laki dan 67 perempuan. Pengambilan data kondisi awal pada tanggal 2127 Juli 2021, sedangkan pengambilan data kondisi akhir pada tanggal 23-27 Agustus 2021. Dalam pengambilan data kondisi awal dan kondisi akhir dengan cara membagikan kuisioner atau angket kepada peserta didik.

\section{HASIL DAN PEMBAHASAN}

Berdasarkan data rekapitulasi hasil kuisioner minat belajar geografi pada kondisi awal dan pada kondisi akhir, diperoleh data persentase minat belajar geografi antara data pada kondisi awal dan data pada kondisi akhir, yang disajikan dalam Gambar 1 berikut.

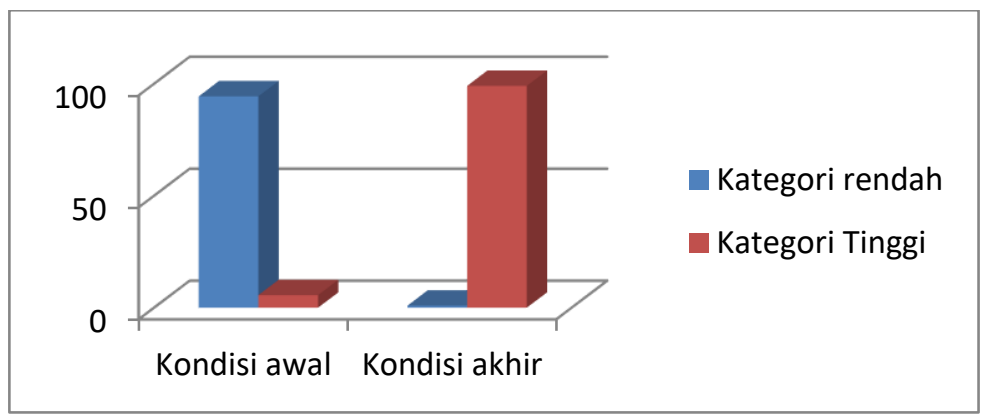

Gambar 1. Histogram Minat Belajar Geografi pada Kondisi Awal dan Kondisi akhir

Berdasarkan Gambar 1, dapat terlihat bahwa persentase minat belajar geografi kategori tinggi pada kondisi awal semula 5,61\% setelah peserta didik diperkenalkan Google Earth dan diajari tentang cara menggunakannya, dalam pembelajaran geografi, persentase minat belajar geografi kategori tinggi pada kondisi akhir menjadi 99,07\%. Oleh karena itu dapat disimpulkan bahwa penggunaan Google Earth dalam pelajaran geografi dapat membangkitkan semangat belajar peserta didik dalam belajar geografi. 
Kondisi peserta didik setelah pelaksanaan best practice ini antar lain: (1) peserta didik senang mengikuti pelajaran geografi, (2) peserta didik rajin aktif dalam mengikuti pembelajaran geografi, (3) peserta didik memperhatikan dan konsentrasi dalam mengikuti pelajaran geografi, (4) peserta didik memiliki kemauan dalam belajar geografi, (5) peserta didik merasa nyaman dalam mengikuti pelajaran geografi, dan (6) peserta didik sudah tidak ragu lagi dalam belajar geografi.

\section{PENUTUP}

Berdasarkan hasil best practice ini, maka dapat diambil simpulan sebagai berikut: (1) Pada pempelajaran geografi sebelum menggunakan Google Earth minat belajar peserta didik dalam kategori rendah, setelah menggunakan Google Earth minat belajar peserta didik menjadi kategori tinggi; (2) Penggunaan Google Earth dalam pembelajaran geografi telah meberikan dampak yang positif, yaitu peserta didik menjadi senang belajar geografi; (3) Pengunaan Google Earth dapat membangkitkan minat belajar geografi pada peserta didik kelas. Berdasarkan hasil best practice ini, maka dapat dikemukakan saran-saran sebagai berikut: (1) Guru geografi agar menggunakan Google Earth dalam pembelajaran, agar peserta didik menjadi senang belajar geografi; (2) Guru hendaknya berinovasi dalam pembelajaran supaya peserta didik tidak bosan dan lebih semangat dalam belajar; (3) Guru hendaknya membuat publikasi ilmiah best practice, yang dapat digunakan dalam penilaian PAK.

\section{DAFTAR PUSTAKA}

Andriani, R., \& Rasto, R. (2019). Motivasi belajar sebagai determinan hasil belajar siswa. Jurnal Pendidikan Manajemen Perkantoran, $4(1)$. https://doi.org/10.17509/jpm.v4i1.14958

Aulia, S (2020). Pembelajaran Daring Pada Masa Pandemi. 20 Juli 2020. https://www.suara.com/yoursay/2020/07/20/175556/pembelajaran-daring pada-masapandemi

Dewi, W. A. F. (2020). Dampak COVID-19 terhadap Implementasi Pembelajaran daring di Sekolah Dasar. Edukatif: Jurnal Ilmu Pendidikan, 2(1) 55-61. https://doi.org/10.31004/edukatif.v2i1.89

Riamin. (2016). Menumbuhkan Minat Belajar Siswa dalam Pembelajaran. 14 April 2016. https://www.kompasiana.com/riamin/570ec6323697738d1a3e38b6/menumbuhkanminat-belajar-siswa-dalam-pembelajaran

Ricardo, R., \& Meilani, R. I. (2017). Impak Minat dan Motivasi Belajar Terhadap Hasil Belajar Siswa. Jurnal Pendidikan Manajemen Perkantoran, 2(2) 79. https://doi.org/10.17509/jpm.v2i2.8108

Yunita, N. W. (2020). Penyebab, Asal Mula, dan Pencegahan Virus Corona di Indonesia. 28 Maret 2020. https://m.detik.com/news/berita/d-4956764/penyebab-asal-mula-dan-pencegahan-viruscorona-di-indonesia

Yunitasari, R. \& Hanifah, U. (2020). Pengaruh Pembelajaran daring terhadap Minat Belajar Siswa pada Masa COVID-19. Edukatif: Jurnal Ilmu Pendidikan. 2(3), 232-243. https://doi.org/10.31004/edukatif.v2i3.142 